\title{
Intravascular Angioleiomyoma
}

National Cancer Institute

\section{Source}

National Cancer Institute. Intravascular Angioleiomyoma. NCI Thesaurus. Code C5355.

A morphologic variant of angioleiomyoma characterized by the adherence of neoplastic smooth muscle cells to the walls of vascular channels. 